\title{
Local Disciplines, local Cultures: \\ Praise and Criticism in British and Spanish History BOOK REVIEWS
}

\begin{abstract}
The use of a critical voice in book reviews seems to depend on factors rooted in the discipline community reviewers belong to and on the language and culture which hosts the review. Adopting a cross-cultural perspective, this study analyses 60 book reviews from British and Spanish history journals in terms of the entities and aspects evaluated and the polarity (positive/negative) of the evaluation. Divergences are found in the distribution of positive and negative evaluation, revealing that even if in both cultures positive evaluation is more frequent, in Spanish book reviews negative evaluation is almost nonexistent. Interviews with informants show that these divergences respond to the local character of the disciplinary communities which host the reviews and to a different understanding of what this evaluative genre implies. ${ }^{1}$
\end{abstract}

Key words

Academic writing; book reviews; cross-cultural analysis; evaluation; disciplinary community

\section{Introduction}

In recent years, there has been an increasing interest in the exploration of evaluation in academic genres. The definition proposed by Hunston and Thompson (2000: 5) in their seminal book Evaluation in Text (evaluation as "the broad cover term for the expression of the speaker or writer's attitude or stance towards, viewpoint on, or feelings about the entities or propositions that he or she is talking about") is by now accepted as an all-encompassing conceptualization, 
broad enough to cater for a variety of linguistic and textual phenomena covered by the umbrella term 'evaluation'. So far a considerable amount of literature has been published on the role of evaluation in highly-conventionalised written genres such as the research article (Thetela 1997; Salager-Meyer 1999; Burgess and Fagan 2002; Oakey 2005; Bellés-Fortuño and Querol-Julián 2010) and the abstract (Stotesbury 2003; Martín-Martín and Burgess 2004), among others. At the moment, a growing body of literature is focusing more specifically on a genre which is, by definition, 'evaluative', as is the case of the book review (Hyland 2000; Gea Valor 2000-2001; Shaw 2004, 2009; Römer 2005, 2008; Tse and Hyland 2009; Groom 2009; Vassileva 2010). Book reviews are meant to act as 'critical windows' which open to the novelties and advances of a given discipline, and, in that sense, they may well contribute to the construction and development of disciplinary knowledge. However, the extent of use of an evaluative voice on the part of the book reviewer does not seem to be as conventionalised as the genre itself might suggest. On the contrary, its use seems to depend on factors that go well beyond the text, and are rooted, most significantly, in the discipline community reviewers belong to and on the language and the national culture which hosts the review. As Hunston (1994: 191) states, "expressing evaluation in a text involves both a statement of personal judgement and an appeal to shared norms and values". The influence of the national culture or language on the expression of evaluation has been widely researched to explore differences, for instance, between English, French and Spanish (Salager-Meyer, Alcaraz Ariza and Zambrano 2003), English and French (Salager-Meyer, Alcaraz Ariza and Pabón 2005), English and Italian (Giannoni 2006; Bondi 2009), and English and Spanish (Salager-Meyer and Alcaraz Ariza 2003; Suárez-Tejerina 2005; Moreno and Suárez 2008a, 2008b, 2009, 2010; Lorés-Sanz 2009). One of their most significant findings for the present study is that, at least in the case of the humanities, book reviews in English display both praise and criticism, sometimes almost to similar levels, whereas Spanish book reviewers tend to avoid negative criticism in their texts, which, as a result, are heavy loaded with praise and do not successfully fulfil their most significant communicative function: the evaluation of new knowledge.

So far, however, there has been little research across languages on the aspects and (lack of) qualities ascribed to the entities under analysis. Thus, this paper seeks to contribute to previous research with an examination of the following questions:

(a) which entities are usually evaluated in book reviews in English and Spanish,

(b) which aspects of those entities are critically assessed in both contexts, either positively or negatively,

(c) whether divergences between both linguistic and cultural contexts are found with respect to the aspects explored above, 
(d) whether these divergences reflect differences in the value-system shared by the members of the disciplinary community which hosts the review.

\section{Methods and materials}

The research questions mentioned above were to be observed in a corpus of book reviews (BRs hereafter) which consisted of texts that originated in the same disciplinary community (historians) but in different linguistic and cultural contexts (Spanish and British). The purpose here was to compare "successful texts written independently as original texts in each of the languages" (Moreno and Suárez 2008a: 505). History is a discipline in which the book review and all the related evaluative genres (the review article, the book note or the book commentary) seem to play a major role in the transmission of new knowledge, manifested in the lengthy sections these genres occupy in the prestigious journals of the discipline.

For the present study $60 \mathrm{BRs}$ were selected (30 from each linguistic/cultural context), amounting to a total of 87,092 words: 52,351 in English and 34,741 in Spanish. The fact that the number of words of the two subcorpora was not comparable did not hinder the results, as normalized results and percentages were dealt with. The corpus was compiled following strict criteria of comparability, according to the guidelines established by Connor and Moreno (2005) and Moreno (2008) and including conditions which refer to the type of text selected: only book reviews and not review articles, book notes or book recommendations were included in the study; they were published in prestigious journals, which assured their success as academic texts, ${ }^{2}$ published in the same time span (between 2000-2007), of comparable length in each language (the Spanish BRs are, obviously, shorter), written by just one (always different) author affiliated to either Spanish or British institutions, and referring to just one book (avoiding edited volumes, proceedings of conferences, etc) which deals with a topic of contemporary history.

The present study focused on the exploration of explicit evaluative acts, that is, those which contain an explicit marker of evaluation. The debate about the implicitness and explicitness of evaluation in a text has been key to the exploration of the role played by evaluation in academic writing. There seems to be general agreement now that the main difference is between propositions which signal their evaluativeness by means of lexical indicators and those that do not, but their evaluativeness depends on the context (Hunston and Thompson 2000; Shaw 2004; Römer 2008). However, the appropriate interpretation of explicit lexical markers of evaluation is not without problems, as will later be seen, and it becomes mandatory to resort to context.

For the identification and tagging of each evaluative act, texts were analysed and searched manually. I conceptualise 'evaluative acts' along the lines of Moreno and Suárez's (2008a, 2008b) 'critical acts', that is, "positive or negative remarks on a given aspect or sub-aspect of the book under review in relation to a criterion of evaluation with a higher or lower degree of generality" (2008b: 18). Such defi- 
nition, which builds on previous and very useful conceptualizations of evaluative units ('praise and criticism' in Hyland 2000) helps overcome the limitations that identification based on the lexicogrammar impose. Thus, evaluative acts are identified as functional units, irrespective of their lexicogrammatical realisations, the requirements being that they contain both the (sub)aspect commented upon and what is said about it (Moreno and Suárez 2008a, 2008b). The following examples illustrate the way the tagging was carried out: ${ }^{3}$

(1) (1-) It has little to say, for instance, about the vast majority of the rural population. (2+) Nevertheless it is a hugely ambitious book $(3+)$ that is not afraid to tackle big questions - the kind that students are wont to ask and specialists loth to answer - and to engage them in $(4+)$ an original, penetrating and compelling fashion. (EHR 8)

(2) Contra lo que pudiera pensarse a priori, $(1+)$ el resultado final en absoluto delata el origen misceláneo de la publicación, lo que deja patente $(2+) \underline{\text { la gran }}$

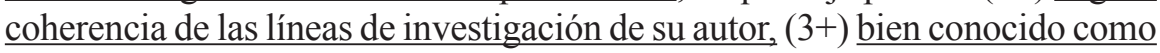
especialista en estudios sobre sociabilidad y cultura en la España contemporánea (HSP9)

[Against what might be initially thought, $(1+)$ the final result does not at all give in the miscelaneous origin of the publication, which highlights $(2+)$ the great coherence of the author's research, $(3+)$ well-known as a specialist on sociability and culture in contemporary Spain. $]^{5}$

For the purposes of the present study, the tagging of evaluative acts took place according to three main categories of information, based on Thetela (1997) and Shaw $(2004,2009)$ :

(i) The 'evaluated entity'. Here 'author' and 'book' emerged as the two main entities under evaluation. Following a corpus-driven methodology (TogniniBonelli 2001), further sub-entities were distinguished:

- with regard to the author the main sub-entities were 'general qualities', which referred to aspects of prestige, competence and experience, and his/her 'research abilities', which had mainly to do with the research tasks carried out to write the book;

- $\quad$ as regards the book itself, the main sub-entities were 'general qualities' (the book in general) and 'parts of the book'. ${ }^{6}$

(ii) The 'value attached' or 'ascribed value', that is, whether the book was original, innovative, interesting or not illuminating enough or whether the author was controversial or well qualified, meticulous, etc.

(iii) The 'polarity of the value': whether it was a positive (praise) or a negative (criticism) evaluative act. 
The tagging of the corpus following this methodological procedure was not without problems. One of the most significant was the use of neutral terms by the book reviewer which acquired an evaluative value in context (Mauranen 2004: 205):

(3) Compared to Norton's other books (Republic of Signs, Bloodrites of the PostStructuralists), Leo Strauss and the Politics of American Empire reads very differently. (HEI 7)

It is not until we continue reading that we interpret very differently in a negative way:

The overall style of the book with its very short, trenchant sentences, and the slightly unusual typesetting testify to the fact that it was not meant for an academic audience.

Or in Spanish:

(4) El resultado del conjunto produce cierta sorpresa al lector: ha sido la confección de un retrato de grupo de los académicos de aquellos años, un magnífico cuadro que en sí mismo valdría la pena por lo que tiene de aportación a la forma de historiar el trabajo intelectual. (HSP1)

[The result of the whole book provokes certain surprise on the reader: it has been the tailoring of the portrait of a group of those years' academics, a magnificent picture which is valuable in itself, because it contributes to the way of making history of intellectual work.]

Surprises can be both good or bad. It is by the interaction of the noun with the adjective magnifico (magnificent) that sorpresa (surprise) is interpreted as praise. Let us compare it with the following example:

(5) Respecto a la justicia franquista, sorprende que, aparte del Juzgado de delitos monetarios, el primer tribunal al que hace referencia el autor sea el de Responsabilidades Políticas. (HSP2)

[With respect to Francoist justice, it is a surprise that, apart from financial crimes, the first court the author makes reference to is the one on Political Responsibilities.]

The text continues in such a way that it makes it clear that the surprise is intended to be interpreted as negative:

Ante este planteamiento el historiador ha de preguntarse si los consejos de guerra celebrados por los militares rebeldes, primero, y utilizados, después, por la administración franquista durante muchos años contra la población civil por actos políticos o criminales, no eran asimismo tribunales de intencionalidad política. 
[Seen in this light, historians have to ask themselves if courts martial firstly held by rebel military men and then used by Francoist administration for many years against civil citizens for accused of criminal or political acts, were not, in the same way, courts with a political intention.]

Given that an analysis of this type is open to interpretation and that a corpusdriven methodology was applied, the data found was submitted to an intra-rater reliability test which consisted in the repetition of the analysis and tagging process of evaluative acts in two BRs from each journal (twelve in all) taken at random. After a span of one month, the test showed a $95 \%$ agreement with the initial procedure.

\section{Results: some quantitative data}

The present study yielded a series of results with respect to the research questions mentioned above. The results found regarding the polarity ascribed to each evaluative act corroborated, in their more general formulation, the conclusions drawn in previous works (Lorés-Sanz 2009, Moreno and Suárez 2009) that positive evaluative acts were always more frequent than negative acts but extremely so in the case of the Spanish BRs, where criticism is almost nonexistent. Table 1 shows my results for the present study:

Table 1. Positive and negative evaluative acts in British and Spanish history BRs. Normalized frequencies per 1,000 words. Raw numbers and percentages in brackets.

\begin{tabular}{|l|c|c|c|}
\hline & Positive & Negative & Total \\
\hline Spanish BRs & $6.7(236)$ & $1.2(42)$ & $8.0(278)$ \\
& $(84.8 \%)$ & $(15.1 \%)$ & $(100 \%)$ \\
\hline British BRs & $6.2(326)$ & $3.4(181)$ & $9.6(507)$ \\
& $(64.29 \%)$ & $(35.7 \%)$ & $(100 \%)$ \\
\hline
\end{tabular}

As seen in this table, the normalized total use of evaluative acts is not very different in both contexts, if slightly higher in English, thus allowing us to conclude that both communities make their texts evaluative to similar degrees. The relevant difference lies in the distribution of positive and negative evaluation, revealing that even if in both cultural contexts positive evaluation is more frequent than negative, ${ }^{7}$ in Spanish BRs this is to the extent that negative evaluation is scarce.

As mentioned above, and along the lines of previous research (Hyland 2000; Shaw 2004; Suárez-Tejerina 2006; Alcalaz-Ariza 2008), the entities evaluative acts were ascribed to were the book evaluated and the author of the book under evaluation. As shown in Table 2 below, evaluation in English is distributed between both entities almost to similar extent whereas in Spanish there is a clear tendency to assess the book critically rather than the author. 
Table 2. Evaluative acts per corpus and entity evaluated in British and Spanish history BRs. Normalized frequencies per 1,000 words. Raw numbers and percentages in brackets.

\begin{tabular}{|l|c|c|c|}
\hline & Author & Book & Total \\
\hline Spanish BRs & $3.1(111)$ & $4.8(167)$ & $8(278)$ \\
& $(39.92 \%)$ & $(60.07 \%)$ & $(100 \%)$ \\
\hline British BRs & $4.7(248)$ & $4.9(259)$ & $9.6(507)$ \\
& $(48.91 \%)$ & $(51 \%)$ & $(100 \%)$ \\
\hline
\end{tabular}

With regard to the author as entity, it was mainly their general qualities (e.g. intelligence, mastery, etc), and their intellectual abilities to carry out and fulfill tasks more specifically related to their research (analysis, argumentation, method followed, etc) which were assessed. However, a few differences were found once a finer reading was carried out. Thus, British reviewers often made reference to the authors' style whereas Spanish reviewers, who did not mention it in the corpus under analysis, included the authors' previous works as a parameter of evaluation, usually for praise:

(6) Despite the discourse of demand curves and profit margins, initially disconcerting for the literary reader, $\underline{\text { St Clair writes in a punchy, lively and acerbic }}$ manner, breathing the spirit of critique into the enormous body of research which has gone into his study. (HWJ6)

(7) En el campo de la investigación (el autor) ha colaborado en el "Instituto Flórez" del C.S.I.C., y publicado muy interesantes trabajos en diferentes revistas, sobre temas eclesiásticos de los siglos XVIII y XIX, elaborados todos ellos a base de documentación desconocida, tomada del rico Archivo Diocesano. (CVC6) [ In the field of research (the author) has collaborated with the "Instituto Flórez" from C.S.I.C. and has published very interesting essays in several journals on ecclesiastic topics of the $18^{\text {th }}$ and $19^{\text {th }}$ century, all of them based on unknown documents extracted from the Diocesan Archive.]

When the entity under evaluation is the book itself, similarities between both cultural contexts are frequent: the book in general is praised or criticised, and also parts of it, like chapters, sections (e.g. the introduction, the prologue, etc), its general content or the research procedures it is based on (focus, methodology, bibliography). Again a few differences arise: British reviewers include praise or criticism of the style of the book, and Spanish book reviewers praise very minor aspects, as the following example shows:

(8) En poco más de 400 páginas, excelentemente impresas, Fuentes va con soltura de lo particular a lo general, de la historia del individuo a la de España y Europa, pero todo lo ve - como cabe exigir al biógrafo - con los ojos de Largo Caballero. (CHC2) 
[In little more than 400 pages, wonderfully printed, Fuentes swifts from the particular to the general, from the history of the individual to the history of Spain and Europe, but he sees all that - as one would expect from a biographer - with Largo Caballero's eyes.]

A more detailed analysis of the data yields the following results, in which calculations have been made with respect to the two main entities evaluated. Thus, with respect to Spanish BRs:

Table 3. Positive and negative evaluative acts referring to the entities evaluated in Spanish BRs. Normalized frequencies per 1,000 words. Raw numbers and percentages in brackets.

\begin{tabular}{|l|c|c|c|}
\hline & Author & Book & Total \\
\hline Positive & $2.9(102)$ & $3.8(134)$ & $6.7(236)$ \\
& $(91.89 \%)$ & $(80.23 \%)$ & $(84.89 \%)$ \\
\hline Negative & $0.2(9)$ & $0.9(33)$ & $1.2(42)$ \\
& $(8.1 \%)$ & $(19.76 \%)$ & $(15.1 \%)$ \\
\hline Total & $3.1(111)$ & $4.8(167)$ & $8(278)$ \\
& $(39.92 \%)$ & $(60.07 \%)$ & $(100 \%)$ \\
\hline
\end{tabular}

As can be observed in Table 3, evaluative acts both about the book and the author are found in Spanish BRs to very different degrees, with the book being the entity of assessment in $60 \%$ of the cases vs the $40 \%$ of evaluative acts referring to the author. This may have to do with the fact that criticising the book is less face threatening than evaluating the author negatively. It may also explain the fact that negative appraisal of the author is barely an $8 \%$ of all the evaluative acts ascribed to authors, whereas when the book is under evaluation, this percentage rises to almost $20 \%$.

Moreover, it was further observed that in Spanish BRs praise and criticism are basically ascribed to general qualities of the book. When criticism appears, it focuses on specific aspects (the title, a certain section, etc). As for the authors, a variety of aspects are evaluated in praising terms, such as their general qualities and their research procedures. As we mentioned before, the category of author's previous works is introduced in Spanish for praise.

In the case of British BRs, the evaluative landscape is slightly different, as shown below:

Table 4. Positive and negative evaluative acts referring to the entities evaluated in British BRs. Normalized frequencies per 1,000 words. Raw numbers and percentages in brackets.

\begin{tabular}{|l|c|c|c|}
\hline & Author & Book & Total \\
\hline Positive & $3.3(173)$ & $2.9(153)$ & $6.2(326)$ \\
& $(69,75 \%)$ & $(59 \%)$ & $(64.29 \%)$ \\
\hline Negative & $1.4(75)$ & $2.0(106)$ & $3.4(181)$ \\
& $(30.24 \%)$ & $(40.92 \%)$ & $(35.7 \%)$ \\
\hline Total & $4.7(248)$ & $4.9(259)$ & $9.6(507)$ \\
& $(48.91 \%)$ & $(51 \%)$ & $(100 \%)$ \\
\hline
\end{tabular}


In contrast to what we found in Spanish BRs, BRs in English show a balance in the evaluation of the author and the book, and even though praise is more frequent than criticism, the presence of negative appraisal is significant enough. Specially balanced is the case of the book, where criticism and praise coexist to not so dissimilar degrees ( $41 \%$ vs $59 \%$ ). Criticism of the author is slightly lower $(30 \%)$. As we argued before, this may be due to the more serious threat that criticising the author implies. However, this percentage is still much higher than the almost non existent critical view on authors that we found in Spanish BRs.

As for the sub-aspects under evaluation, in British BRs both general and specific points are praised and criticised. In the case of the book, the general qualities tend to be praised and the content criticised. Other features which are praised are parts of the book and research. In contrast, together with content, when style is mentioned it is often criticised.

In the case of the author, subaspects usually praised are general qualities, research procedures, choice of content and style. Criticism is ascribed to more specific aspects and never to the intellectual qualities of the author.

The tendency to praise the author and criticise the book is exemplified in the following fragment from a British BR, which shows how these two forces at work can combine in a single sentence:

(9) While she is clearly right to resist demands for simplistic explanations that demonise Strauss (or the philosophers he read and recommended, such as Plato for instance), one cannot fail to notice the absence from Norton's book of any analysis of Strauss's texts that could suggest a link, however, tentative and provisional, with the subsequent course of the epigonoi. (HEI 7)

Further exploration of the corpus showed interesting observations which were only ascribable to one or the other cultural context. This is the case, for instance, of the use of humour and irony as a way of conveying negative evaluation. Ironic comments are found in British BRs, all of them related to the author. Nothing similar is found in the Spanish texts. Example 10 is a good illustration of it:

(10) Roberts rejoices with Bragg (Melvyn, not Billy) in the fact that, apparently, we can still have conversations in Old English and with Crystal (described as a historian) in the claim that English is the most etymologically multilingual language on earth. (EHR 1)

Melvyn Bragg is a writer and broadcaster; Billy Bragg is an alternative rock musician and left-wing activist. It is meant to be understood as an ironic comment since one of the critical strands in this particular BR is the conservative position of the author with respect to certain cultural and historical issues related to the hegemony of the English language. 
As regards the Spanish BRs, other remarkable features were also observed. One of them was the tendency to praise what we might call 'the craft of the discipline'. These are a few examples:

(11) El historiador, el autor del libro lo es -y de los buenos -, interpreta y explica estas actitudes, que expuestas en el tránsito del siglo XIX al XX no dejan de resultar sumamente sorprendentes, a pesar de todo. (PM 2)

[The historian, the author of the book is one of them, - and one of the best ones - interprets and explains these attitudes, that in the transition from the $19^{\text {th }}$ to the $20^{\text {th }}$ century become surprising, in spite of everything.]

(12) Ahora bien, como buen historiador - y, por lo tanto, cauto - no se atreve a inferir del caso argentino un modelo general para todo el continente. (PM 7) [Now, as a good historian - and therefore, cautious - does not dare to infer from the Argentinian case a general model for all the continent.]

Thus, not being a member of the discipline community, not being a historian, is one reason for open criticism:

(13) El libro del jurista R. Cancio Fernández capta la atención del lector interesado por estas cuestiones desde el mismo título, por su planteamiento amplio que abarca toda la guerra e incluye la administración republicana y la franquista [...]. Sin embargo, aquel interés disminuye a medida que van pasando las páginas porque el trabajo del jurista apenas supera la mera ordenación cronológica de las disposiciones legales [...]. Pero a estas cuestiones no responde el jurista, ni siquiera se las plantea. (HSP 2)

[The book by the jurist R. Cancio Fernández captures, from the very title, the attention of the reader interested in these questions, for its wide approach, which covers all the war and includes the Republican and the Francoist administration [...]. Nevertheless, that interest decreases as the pages are left behind because the jurist's work hardly goes beyond the mere chronological organization of legal dispositions [...]. But to these questions, the jurist does not respond, he does not even think about them.]

Another recurrent feature of Spanish book reviewers is the tendency to frame authors in their academic environment and to refer to their previous works.

(14) Esta obra recoge parte de la Tesis Doctoral del autor, dirigida por el profesor Luis Enrique Otero Carvajal, y brillantemente defendida en la Universidad Complutense de Madrid en enero de 2004. (CHC4)

[This essay is part of the author's PhD thesis, supervised by Dr Luis Enrique Otero Carvajal and brilliantly defended at the Universidad Complutense de Madrid in January 2004.] 
(15) No es este el caso del libro que ahora reseñamos pues su autor, David Guinard i Feron, que ha dejado cumplida muestra de su profesionalidad como director de Quaderns d'Historia Contemporania de les Balears, se interna es esta ocasión en un periodo tan convulso como el que va, básicamente, de 1930 a 1942. (HSP 8)

[This is not the case of the book under review, as his author, David Guinard i Feron, that has left proven record of his professionalism as director of Quaderns d'Historia Contemporania de les Balears, this time investigates a tumultuous period that basically stretches from 1930 to 1942.]

The recurrent feature of contextualizing the author in the profession shows the tendency to highlight the author's membership in the discipline community of historians, a local community in which everybody knows everybody. In this way book reviewers tell their readers who this member is in the small family of Spanish historians.

The present study also included an exploration of the lexico-grammatical devices used to express evaluation both positively and negatively. A record was made of word classes and tokens which appeared in the corpus. Both Spanish and English BRs include evaluation by means of four classes of word: adjectives, verbs, adverbs and nouns. The analysis focused on the lexical expressions ascribed to authors and books in one and the other language. In both languages authors were found to be evaluated mainly by means of verbs. Adverbs and adjectives were found to be quite frequent to evaluate authors positively in both languages whereas they were very scarcely used to evaluate authors negatively. Nouns were much more frequently used in Spanish, but only for positive evaluation. The table on the next page includes a repertoire of verbs, adjectives, adverbs and nouns ascribed to authors in English and Spanish. 
Table 5. Evaluative verbs, adjectives, adverbs and nouns ascribed to authors in British and Spanish BRs.

\begin{tabular}{|c|c|c|c|c|}
\hline & \multicolumn{2}{|l|}{ British BRs } & \multicolumn{2}{|l|}{ Spanish BRs } \\
\hline & Positive & Negative & Positive & Negative \\
\hline Verbs & $\begin{array}{l}\text { achieve } \\
\text { convince } \\
\text { demonstrate } \\
\text { fill a gap } \\
\text { make a point } \\
\text { make clear } \\
\text { reveal } \\
\text { succeed }\end{array}$ & $\begin{array}{l}\text { enmesh } \\
\text { give less atten- } \\
\text { tion } \\
\text { exaggerate } \\
\text { underestimate }\end{array}$ & $\begin{array}{l}\text { acierta } \\
\text { consigue } \\
\text { demuestra } \\
\text { logra } \\
\text { tiene razón }\end{array}$ & $\begin{array}{l}\text { no responde } \\
\text { no trata } \\
\text { pasa por alto }\end{array}$ \\
\hline Adjectives & $\begin{array}{l}\text { astute } \\
\text { conscious } \\
\text { correct } \\
\text { innovative } \\
\text { meticulous } \\
\text { persuasive } \\
\text { attractive } \\
\text { right } \\
\text { sensitive } \\
\text { systematic } \\
\text { perceptive } \\
\text { well qualified }\end{array}$ & $\begin{array}{l}\text { novel } \\
\text { weak } \\
\text { wrong }\end{array}$ & $\begin{array}{l}\text { admirable } \\
\text { bien conocido } \\
\text { buen historiador } \\
\text { cauto } \\
\text { capaz } \\
\text { eficaz, especialista } \\
\text { más indicado } \\
\text { incuestionable } \\
\text { inteligente } \\
\text { prolifico }\end{array}$ & controvertido \\
\hline Adverbs & $\begin{array}{l}\text { clearly } \\
\text { right } \\
\text { convincingly } \\
\text { correctly } \\
\text { effectively } \\
\text { fruitfully } \\
\text { intelligently } \\
\text { patiently } \\
\text { rightly } \\
\text { valiantly } \\
\text { astutely } \\
\text { cunningly } \\
\text { carefully } \\
\text { vividly }\end{array}$ & confusingly & $\begin{array}{l}\text { acertadamente } \\
\text { con acierto } \\
\text { de forma brillante } \\
\text { de modo sistemático, } \\
\text { extraordinariamente }\end{array}$ & (none found) \\
\hline Nouns & $\begin{array}{l}\text { mastery } \\
\text { sensitivity } \\
\text { erudition } \\
\text { integrity } \\
\text { sympathy } \\
\text { thoroughness }\end{array}$ & (none found) & $\begin{array}{l}\text { capacidad analítica } \\
\text { criterio } \\
\text { coherencia } \\
\text { esfuerzo } \\
\text { interés } \\
\text { precisión } \\
\text { profesionalidad } \\
\text { talla investigadora } \\
\text { gran inteligencia }\end{array}$ & (none found) \\
\hline
\end{tabular}

With regard to books a different picture emerges. In both languages books are assessed mainly by means of adjectives. Evaluative adverbs, verbs and nouns ascribed to books are also found in both languages. Table 6 below displays examples of all the word classes: 
Table 6. Evaluative verbs, adjectives, nouns and adverbs ascribed to books in British and Spanish BRs.

\begin{tabular}{|c|c|c|c|c|}
\hline & \multicolumn{2}{|l|}{ British BRs } & \multicolumn{2}{|l|}{\begin{tabular}{|l|} 
Spanish BRs \\
\end{tabular}} \\
\hline & Positive & Negative & Positive & \begin{tabular}{|l|} 
Negative \\
\end{tabular} \\
\hline Adjectives & $\begin{array}{l}\text { ambitious } \\
\text { best } \\
\text { brilliant } \\
\text { central } \\
\text { major } \\
\text { useful } \\
\text { elegant } \\
\text { sophisticated } \\
\text { excellent origi- } \\
\text { nal ground- } \\
\text { breaking im- } \\
\text { portant impres- } \\
\text { sive interesting } \\
\text { outstanding } \\
\text { rare and wel- } \\
\text { come } \\
\text { refreshing seri- } \\
\text { ous } \\
\text { suggestive } \\
\text { superb thought- } \\
\text { provoking }\end{array}$ & $\begin{array}{l}\text { arbitrary } \\
\text { confusing } \\
\text { disconcerting } \\
\text { flawed } \\
\text { fragmentary } \\
\text { questionable } \\
\text { mudding } \\
\text { not illuminating } \\
\text { unreadable } \\
\text { not sufficient } \\
\text { weak }\end{array}$ & $\begin{array}{l}\text { acertado } \\
\text { ambicioso } \\
\text { amplio } \\
\text { bien escrito } \\
\text { crucial } \\
\text { detallado } \\
\text { documentado } \\
\text { excelente } \\
\text { exhaustivo } \\
\text { extraordinario } \\
\text { importante } \\
\text { inteligente } \\
\text { interesante } \\
\text { magnifico } \\
\text { original } \\
\text { preciso } \\
\text { provocador } \\
\text { relevante } \\
\text { rico } \\
\text { riguroso } \\
\text { sistemático } \\
\text { sobresaliente } \\
\end{array}$ & \begin{tabular}{|l} 
breve \\
corto \\
débil \\
desdibujado \\
engañoso \\
insignificante \\
irregular
\end{tabular} \\
\hline Verbs & $\begin{array}{l}\text { challenge } \\
\text { compensate } \\
\text { enrich } \\
\text { help } \\
\text { make clear } \\
\text { does not ignore } \\
\text { reward } \\
\text { show }\end{array}$ & $\begin{array}{l}\text { (does not) deliver } \\
\text { (does not) excite } \\
\text { fail to notice } \\
\text { hardly differs } \\
\text { lack } \\
\text { limit } \\
\text { underestimate }\end{array}$ & $\begin{array}{l}\text { aportar } \\
\text { ayudar } \\
\text { captar la atención } \\
\text { mostrar } \\
\text { ofrecer respuestas } \\
\text { poner de manifiesto }\end{array}$ & $\begin{array}{l}\text { condiciona } \\
\text { echa de menos } \\
\text { no se consigue }\end{array}$ \\
\hline Nouns & $\begin{array}{l}\text { achievement } \\
\text { interest } \\
\text { relevance } \\
\text { richness } \\
\text { strength }\end{array}$ & $\begin{array}{l}\text { criticism } \\
\text { disappointment } \\
\text { limitations } \\
\text { no analysis } \\
\text { obscurity } \\
\text { parochialism } \\
\text { superficiality } \\
\text { weariness }\end{array}$ & \begin{tabular}{|l} 
acierto \\
aportación \\
claridad \\
originalidad \\
importancia \\
interés \\
logro \\
mérito minuciosidad \\
atractivo \\
novedad \\
profundidad \\
rigor \\
utilidad \\
valor \\
\end{tabular} & $\begin{array}{l}\text { carencia } \\
\text { despropósito } \\
\text { errores } \\
\text { omisión } \\
\text { reiteración } \\
\text { tópico }\end{array}$ \\
\hline Adverbs & $\begin{array}{l}\text { extremely } \\
\text { extensively } \\
\text { highly }\end{array}$ & $\begin{array}{l}\text { deeply } \\
\text { typically } \\
\text { unlikely } \\
\text { very }\end{array}$ & \begin{tabular}{|l|} 
excelentemente \\
perfectamente \\
brillantemente \\
elegantemente
\end{tabular} & brevemente \\
\hline
\end{tabular}




\section{Voices from the discipline: some qualitative findings}

To gather some qualitative information which could complement and explain the quantitative findings, a survey was carried out among the book reviewers whose texts were selected for the present study and among the editors of the journals from where the texts were extracted. Feedback was obtained from 12 book reviewers (six British and six Spanish) and three editors (two British and one Spanish). The answers provided to the survey may shed an explanatory light on the results obtained in this piece of research and help explain the role of discipline and culture in evaluation.

The fact that negative evaluation is almost nonexistent in Spanish BRs, which reveals the lack of what we might call a 'critical spirit', might be ascribable to four factors which are somehow mentioned in the informants' answers: ${ }^{8}$

(i) In the Spanish academic milieu to criticise a colleague's work publicly might be thought to be a culturally unacceptable behaviour. See the following comment by a Spanish editor:

"Scientific debate is hardly welcomed, and any objection - of approach or method - is interpreted as offensive, if not by the author him/herself, at least by the bulk of the discipline community."

(ii) British and Spanish historians show a divergent attitude towards the BR as an academic genre that can be trusted as a repository of disciplinary knowledge: "Discounting for known positions, they are no more unreliable/subjective then anything else academic." (British book reviewer)

"I have the impression that some reviews just reveal hatred towards the author of the book or a relationship with him/her, who frequently is the person who commissions it." (Spanish book reviewer)

(iii) In the Spanish academic context, writing BRs is given a very low rate as contributions to one's academic career:

"Book reviews are not well rated in CVs or in the professional activity in general in Spain whereas in other countries they can become a key element in the advancement of academic disciplines. (Spanish book reviewer)

(iv) British and Spanish historians reveal a different understanding of what the aim of a book review should be:

"To explore the wider issues raised by the book and develop the arguments. Locate them in wider fields of historical debate. They shouldn't be checklists of merits and demerits." (British editor) 
"A summary of content, the assessment of the book and information about the author, all in the right proportion depending on the interest of each of them (sometimes the author is more relevant than the book)." (Spanish editor)

All these factors indicate that Spanish BRs are not a site for knowledge construction and epistemological enquiry, as they seem to be in the British context. In the Spanish academic community, at least as far as historians are concerned, BRs are a site for strengthening bonds with peers, a site where authors as subjects become more important than books as objects and where junior academics may find some room to train themselves as novel writers.

\section{Discussion of results and concluding remarks}

The purpose of the current study was to uncover the differences in the way the disciplinary community of historians convey evaluation in two distinct linguistic and cultural contexts, and to explore how local contexts can influence the extent and expression of evaluation in the BR.

Significant differences have been recorded between both linguistic/cultural communities in the way they convey evaluation in BRs. To start with, this study found that the overall use of evaluative acts is similar in both subcorpora in terms of frequency, thus allowing us to conclude that both communities make their texts evaluative to similar degrees. More significant, however, are the differences found in the distribution of positive and negative evaluative acts, revealing that in both sets of texts positive evaluation is more frequent than negative. In Spanish BRs, however, negative evaluation is almost nonexistent. This research has also shown that in British BRs the author and the book are evaluated almost to similar degrees, whereas in Spanish there is a clear tendency to assess the book critically rather than the author. Differences were also recorded in the aspects of both entities which were subjected to evaluation.

Further features which typify distinct textual conventions in the expression of evaluation in British and Spanish BRs were also observed. These features constitute peculiarities of one and the other linguistic and cultural community, referring for instance to use of irony in one case and contextualistion of the author's previous merits and work in the other. In all, it seems to be the case that significantly distinct textual expressions and realisations of evaluation in the two subcorpora under study need to be looked for and explained within the cultural and sociopragmatic context in which the texts emerged.

In the case of distinct cultural and linguistic communities, several factors can be identified which may account for the recorded differences in terms of evaluation. Following Okamura (2000, in Shaw 2003: 344ff) some of these factors are: 
- The 'national culture', which may be equated to Holliday's concept of 'large culture' (1999), and which refers to "our expectation that members of different cultures have learned different ways of expressing themselves generally and that these affect academic writing" (Shaw 2003: 345).

- The 'national science' which refers to the local disciplinary culture or community, whose common set of conventions conditions the production of the academic texts which emerge in it.

- The audience for which the text is produced, which can be distinguished in terms of degree of localism and degree of specialisation.

Shaw (2003: 245) adds a fourth factor which is discipline itself, not only because style and rhetoric differ across disciplines but also because there are "national science' differences in one discipline but they may not exist in another, where disciplinary behaviour can be found to be quite homogeneous across national cultures.

The difficulties for the academic writer may therefore appear when the expected matching between national culture (language), national science (local disciplinary community), and the audience is disrupted. This disruption may happen, for instance, when a text is drafted attending to the value-system of a local community (e.g. Spanish) but is written in a language not usually associated to that local community (e.g. English) and is addressed to a different audience (e.g. published in an international journal). When such a mismatch happens, expectations from the readers may not be fulfilled, the text may not play its role to a satisfactory degree, and, in the worst case, the author may have difficulties in having his/her text accepted for publication.

As Hyland (2000: 1) states, "to study the social interaction expressed through academic writing is not only to see how writers in different disciplines (and I would add, in different linguistic cultures) go about producing knowledge, it is also to reveal something of the sanctioned social behaviours, epistemic beliefs and institutional structures of academics". The results and findings from the present study seem to suggest that evaluation is not (or at least, not only) an individual cognitive act which then finds its linguistic realization in the text. It has long been shown that evaluation is a discoursal phenomenon, and not the product of the lexicogrammar (Hunston 1994; Thetela 1997; Hunston and Thompson 2000; Moreno and Suárez 2008a). And, most importantly, it is the result of what Hyland (2000: 1) describes for academic writing in general as 'a collective social practice', which reflects the values, norms, conventions, beliefs or attitudes, that is, the whole value-system, shared by a community.

\section{Notes}

1 This contribution is part of a research project financed by the Spanish Ministry of Science and Innovation, Plan Nacional de I+D+i (2008-2011), Ref: FFI2009-08336.

2 The prestige of the publications from which book reviews were selected was assured by 
their inclusion in the European Reference Index for the Humanities (ERIH) of the European Science Foundation. The journals in English were English Historical Review (rank A); History of European Ideas (rank B); History Workshop Journal (rank A). The Spanish Journals included: Cuadernos de Historia Contemporánea (rank B); Hispania: Revista Española de Historia (rank A); Pasado y Memoria (rank B).

The tagging in the examples indicate the number of the evaluative act $(1,2,3$, etc) and its polarity (a plus symbol for positive polarity and a minus symbol for negative polarity). The evaluative (positive or negative) remarks on a given aspect are underlined.

The acronyms used for the journals included in the corpus are: HER (English Historical Review), HEI (History of European Ideas), HWJ (History Workshop Journal), CHC (Cuadernos de Historia Contemporánea); HSP (Hispania: Revista Española de Historia) and PM (Pasado y Memoria). The number accompanying the acronym indicates the text the example has been taken from.

My translation.

6 Similar entities are found in Alcaraz-Ariza (2008).

7 In a study published in the Journal of Academic Librarianship, Greene and Spornick echoed a common complain about "the propensity of the book review media to publish favorable reviews" (1995: 449). One interesting data from their study revealed that for History BRs, published in high impact English-medium journals, 70.6\% were categorised as 'favourable', $4.2 \%$ as 'unfavourable' and $25.1 \%$ as 'mixed or no opinion'.

8 For space limitations, only the translations into English of the Spanish informants' answers are provided. Full answers by editors and book reviewers are included in the Appendix. In the text only short quotations are included.

\section{Acknowledgements}

I would like to thank Dr Ana Moreno for her precious advice and help in the design of the corpus compiled for the present study.

\section{References}

Alcaraz-Ariza, María Ángeles (2008) 'Las reseñas de libros médicos escritas en español: un estudio sociopragmático de las expresiones de alabanza'. Ibérica 16, 37-58.

Bellés-Fortuño, Begoña and Mercedes Querol-Julián (2010) 'Evaluation in research article abstracts: A cross-cultural study between Spanish and English medical discourse'. In: Lorés-Sanz, Rosa, Pilar Mur-Dueñas and Enrique Lafuente-Millán (eds.) Constructing Interpersonality: Multiple Perspectives on Written Academic Genres. Newcastle-upon-Tyne: Cambridge Scholars Publishing, 83-98.

Bondi, Marina. (2009) 'Historians at work: Reporting frameworks in English and Italian book review articles'. In: Hyland, Ken and Giuliana Diani (eds.) Academic Evaluation. Review Genres in University Settings. Basingstoke: Palgrave Macmillan, 179-196.

Burgess, Sally and Anna Fagan (2002) '(Kid) Gloves on or off? Academic conflict in research articles across the disciplines'. Revista Canaria de Estudios Ingleses 22, 79-96.

Connor, Ulla and Ana I. Moreno (2005) 'Tertium Comparationis: A vital component in contrastive research methodology’. In: Bruthiaux, Paul, Dwight Atkinson, William Eggington, William Grabe and Vaidehi Ramanathan (eds.) Directions in Applied Linguistics: Essays in Honor of Robert B. Kaplan. Clevedon, England: Multilingual Matters, 153-164.

Gea Valor, María Lluïsa (2000-01) 'The pragmatics of positive politeness in the book reviews'. RESLA 14, 145-159. 
Giannoni, Davide S. (2006) 'Expressing praise and criticism in Economic discourse: A comparative analysis of English and Italian book reviews'. In: Del Lungo Camiciotti, Gabriella, Marina Dossena and Belinda Crawford Camiciottoli (eds.) Variation in Business and Economics Discourse. Diachronic and Genre Perspectives. Roma: Officina Edizioni, 126-138.

Greene, Robert J. and Charles D. Spornick (1995) 'Favorable and Unfavorable Book Reviews: A Quantitative Study'. Journal of Academic Librianrianship 21 (6), 449-453.

Groom, Nicholas (2009) 'Phraseology and epistemology in academic book reviews: A corpus-driven analysis of two humanities disciplines'. In: Hyland, Ken and Giuliana Diani (eds.) Academic Evaluation. Review Genres in University Settings. Basingstoke: Palgrave Macmillan, 122-139.

Holliday, Adrian (1999) 'Small Cultures'. Applied Linguistics 20 (2), 237-264.

Hunston, Susan (1993) 'Evaluation and ideology in scientific writing'. In: Ghadessy, Moshen (ed.) Register analysis: Theory and Practice. London: Pinter Publishers, 57-73.

Hunston, Susan (1994) 'Evaluation and organization in a sample of written academic discourse'. In: Coulthard, Malcolm (ed.) Advances in Written Text Analysis. London: Routledge, 191-218.

Hunston, Susan and Geoff Thompson (2000) Evaluation in Text. Authorial Stance and the Construction of Discourse. Oxford: OUP.

Hyland, Ken (2000) Disciplinary Discourses. Social Interactions in Academic Writing. London: Longman.

Lorés-Sanz, Rosa (2009) '(Non-)critical voices in the reviewing of history discourse: A crosscultural study of evaluation'. In: Hyland, Ken and Giuliana Diani (eds.) Academic Evaluation. Review Genres in University Settings. Basingstoke: Palgrave Macmillan, 143-160.

Martín Martín, Pedro and Sally Burgess (2004) 'The rhetorical management of academic criticism in research article abstracts'. Text 24 (2), 171-195.

Mauranen, Anna (2004) 'Where next? A summary of the round table discussion'. In: Del Lungo Camiciotti, Gabriella and Elena Tognini-Bonelli (eds.) Academic Discourse - New Insights into Evaluation. Bern: Peter Lang, 203-216.

Moreno, Ana I. (2008) 'The importance of comparable corpora in cross-cultural studies'. In: Connor, Ulla, Ed Nagelhout and William Rozycki (eds.) Contrastive Rhetoric: Reaching to Intercultural Rhetoric. Amsterdam: John Benjamins, 25-41.

Moreno, Ana I. and Lorena Suárez (2008a) 'A framework for comparing evaluation resources across academic texts'. Text \& Talk 28 (4), 501-521.

Moreno, Ana I. and Lorena Suárez (2008b) 'A study of critical attitude across English and Spanish academic book reviews'. Journal of English for Academic Purposes 7, 15-26.

Moreno, Ana I. and Lorena Suárez (2009) 'Academic book reviews in English and Spanish: Critical comments and rhetorical structure'. In: Hyland, Ken and Giuliana Diani (eds.) Academic Evaluation. Review Genres in University Settings. Basingstoke: Palgrave Macmillan, 161-178.

Moreno, Ana I. and Lorena Suárez (2010) 'Academic book reviews in English and Spanish: Is 'giving reasons for critical comments a universal politeness strategy?' In: Lorés-Sanz, Rosa, Pilar Mur-Dueñas and Enrique Lafuente-Millán (eds.) Constructing Interpersonality: Multiple Perspectives on Written Academic Genres. Newcastle-upon-Tyne: Cambridge Scholars Publishing, 137-160.

Oakey, David (2005) 'Academic vocabulary in academic discourse: The phraseological behaviour of Evaluation in Economics research articles'. In: Tognini-Bonelli, Elena and Gabriella Del Lungo Camiciotti (eds.) Strategies in Academic Discourse. Amsterdam: John Benjamins, 169-183.

Okamura, Akiko (2000) The roles of culture, sub-culture and language in scientific research articles. Unpublished PhD thesis, Newcastle-upon-Tyne: University of Newcastle upon Tyne.

Römer, Ute (2005) 'This seems somewhat counterintuitive, though...: Negative evaluation in linguistic book reviews by male and female authors'. In: Tognini-Bonelli, Elena and Gabriella Del Lungo Camiciotti (eds.) Strategies in Academic Discourse. Amsterdam: John Benjamins, 97-115.

Römer, Ute (2008) 'Identification impossible? A corpus approach to realisations of evaluative meaning in academic writing'. Functions of Language 15 (1), 115-130.

Salager-Meyer, Francoise and María Ángeles Alcaraz Ariza (2003) 'Academic criticism in Spanish 
medical discourse: a cross-generic approach'. International Journal of Applied Linguistics 13 (1), 96-114.

Salager-Meyer, Francoise, María Angeles Alcaraz Ariza and Maryelis Pabón (2005) 'The prosecutor and the defendant: Contrasting Critical Voices in French- and English-Written Academic Book Reviews'. In: Flottum, Kjerstin (ed.) Language and Discipline Perspectives on Academic Discourse. Cambridge: Cambridge University Press, 109-127.

Salager-Meyer, Francoise, María Angeles Alcaraz Ariza and Nahirana Zambrano (2003) 'The scimitar, the dagger and the glove: intercultural differences in the rhetoric of criticism in Spanish, French and English medical discourse (1930-1995)'. English for Specific Purposes 22 (3), 223-247.

Salager-Meyer, Francoise (1999) 'From "Mr. Guthrie is profoundly mistaken..." to "Our data do not seem to confirm the results of a previous study on...": A diachronic study of polemicity in academic writing (1810-1995)'. Ibérica 1, 5-28.

Shaw, Philip (2003) 'Evaluation and promotion across languages'. Journal of English for Academic Purposes 2, 343-357.

Shaw, Philip (2004) 'How do we recognise implicit evaluation in academic book reviews'. In: Del Lungo Camiciotti, Gabriella and Elena Tognini-Bonelli (eds.) Academic Discourse - New Insights into Evaluation. Bern: Peter Lang, 121-140.

Shaw, Philip (2009) 'The lexis and grammar of explicit evaluation in academic book reviews, 1913 and 1993'. In: Hyland, Ken and Giuliana Diani (eds.) Academic Evaluation. Review Genres in University Settings. Basingstoke: Palgrave Macmillan, 217-235.

Stotesbury, Hilkka (2003) 'Evaluation in research article abstracts in the narrative and hard sciences'. Journal of English for Academic Purposes 2, 327-341.

Suárez Tejerina, Lorena (2006) Mode of Evaluation and Rhetorical Patterns: A Contrastive Study of English and Spanish Book Reviews. Unpublished PhD thesis. León: Universidad de Léon.

Suárez-Tejerina, Lorena (2005) 'Is evaluation structure-bound? An English-Spanish contrastive study of book reviews'. In: Tognini-Bonelli, Elena and Gabriella Del Lungo Camiciotti (eds.) Strategies in Academic Discourse. Amsterdam: John Benjamins, 117-131.

Thetela, Puleng (1997) 'Evaluated entities and parameters of value in academic research articles'. English for Specific Purposes 16 (2), 101-118.

Tognini-Bonelli, Elena (2001) Corpus Linguistics at Work. Amsterdam: Benjamins.

Tse, Polly and Ken Hyland (2009) 'Discipline and gender: Constructing rhetorical identity in book reviews'. In: Hyland, Ken and Giuliana Diani (eds.) Academic Evaluation. Review Genres in University Settings. Basingstoke: Palgrave Macmillan, 105-121.

Vassileva, Irena (2010) 'Critical book reviews in German'. International Journal of Applied Linguistics 20 (3), 354-367.

\section{Appendix: Further comments of British and Spanish editors and book reviewers}

"Discounting for known positions, they are no more unreliable/subjective then anything else academic. (British book reviewer)

"On the whole, yes, I trust book reviews" (British book reviewer)

"To explore the wider issues raised by the book and develop the arguments. Locate them in wider fields of historical debate. They shouldn't be checklists of merits and demerits". (British editor)

"To discuss a book, present findings to a wider audience and assess how (positively or negatively) it changes the scholarly community perception" (British editor) 
"Synopsis of argument, implications for the field. Book reviews are not summaries! Or mini-biographies of authors. No need to refer to authors" (British editor)

"They should provide a description of the subject matter, an outline of chapters, a summary of the author's argument, a judgement of the quality of the book, scholarly depth and contribution to field" (British book reviewer)

“(the book review) hasn't lost prestige but is underrated or even feared. Scientific debate is hardly welcomed, and any objection - of approach or method- is interpreted as offensive, if not by the author him/herself, at least by the bulk of the discipline community." (Spanish editor)

"I have the impression that some reviews just reveal hatred towards the author of the book or a relationship with him/her, who frequently is the person who commissions it." (Spanish book reviewer)

"Yes, I read book reviews, if I trust the author. I don't if they are more useful as summaries than as critical approaches" (Spanish book reviewer)

"Depends on who writes them. I wouldn't trust them if I didn't know who writes them" (Spanish book reviewer)

"It is usually young researchers who write them, because they are working with bibliography and it's a good way to start publishing and to get to know the authors. Unfortunately, senior researchers do no tend to write book reviews. [...] Seniors make use of more efficient ways to exert power: they control the most important publishing houses, they are part of scientific committees, they evaluate research programs and assess candidates for tenure or as researchers." (Spanish book reviewer)

"Book reviews are not well rated in CVs or in the professional activity is general in Spain whereas in other countries they can become a key element in the advancement of academic disciplines. (Spanish book reviewer)

"A book review should include the contextualization of the book in the author's trajectory, and a state of the question" (Spanish book reviewer)

"The purpose of a book review should be to analyse which new elements the book contributes with to the topic in question and to the discipline in general. It should a state of question, references to the author, content of the book and sources, and which novelties the book contributes with, although sometimes book reviews in Spain are mere summaries". (Spanish book reviewer)

"A summary of content, the assessment of the book and information about the author, all in the right proportion depending on the interest of each of them (sometimes the author is more relevant than the book)". (Spanish editor)

Rosa LoRÉs-SANZ is a senior lecturer in the Department of English and German Studies of the University of Zaragoza, where she teaches Linguistics and Translation. Her research focuses on the exploration of rhetorical and metadiscoursal features in written academic genres, mainly from a cross-cultural perspective. She has published her results in international journals such as English for Specific Purposes, Text and Talk and Journal of English for Academic Purposes.

Address: Rosa Lorés-Sanz, Departamento de Filología Inglesa y Alemana, Facultad de Filosofía y Letras, Universidad de Zaragoza, C/ Pedro Cerbuna nº 12, 50009 Zaragoza, Spain. [e-mail: rlores@ unizar.es] 